organic production, circulation, and labeling of organic products» in Ukraine. The author substantiates the requirements for production, production control (certification), and defines the responsibilities for noncompliance with the requirements. The requirements for the most common types of labeling «bio», «eco», «organic» are described. The emphasis is laid on the benefits of meeting the high standards of the organic product quality, which is a ground for the introduction of the world trends regarding the circulation of organic products and active support of it at the legislative level in Ukraine. The new law not only raises the standards of production of organic products, which is a positive phenomenon, but also increases the burden on the national producer. The results of the study show that compliance with the Law of Ukraine « On Basic Principles and Requirements for Organic Production, Circulation, and Labeling of Organic Products» extends the target market for agricultural products to the producer and simplifies the procedures for its export to other countries. The growing level of hygienic requirements and food safety standards on the world market necessitates the introduction of world standards for the circulation of organic products at the legislative level in Ukraine. The introduction in Ukraine of registers operators, certification bodies, organic seeds and planting material will allow citizens, market participants of organic products, market participants, other interested parties to receive up-to-date, verified information about organic market operators, certification bodies eligible for certification of organic production or circulation of organic products, as well as the availability on the market of Ukraine of organic seeds and planting material.

Key words: organic products, certification of organic products, labeling «bio», «eco», «organic», administrative responsibility.

УДК - 343.132

DOI https://doi.org/10.32782/2409-4544/2019-2/23

О. Ліщинська-Мартинюк

\title{
Тактика пред’явлення особи для впізнання крізь призму врахування психічного стану неповнолітніх потерпілих від насильницьких злочинів
}

У статті висвітлюються питання особливостей психічного стану неповнолітніх потерпілих від насильницьких злочинів. Розкрито особливості психіки неповнолітніх в різні вікові періоди і звичайні реакції на психологічну травму. Особливу увагу приділено обліку психічних станів неповнолітніх потерпілих від насильницьких злочинів при організації пред'явлення особи для впізнання. Обгрунтовано положення про те, що психічний стан неповнолітніх потерпілих від насильницьких злочинів знаходить свій вияв у своєрідності їх психічних процесів, є основою формування показань і обумовлює певні спотворення первинної інформації про злочин і має бути досліджено і враховано слідчим при виборі тактики пред'явлення неповнолітньому потерпілому для впізнання іншого людини. Тривалість, ступінь i характер впливу психічного стану на неповнолітнього потерпілого, ступінь його усвідомленості постраждалим, адекватність ситуації, домінування в ньому того чи іншого компонента впливають на обрання слідчим тактики слідчих дій за участю потерпілого, на оцінку слідчим його показань, отриманих при пред'явленні для впізнання. Напружено-емоційний стан неповнолітнього потерпілого суттєво гальмують процес відтворення ним показань. Тому з урахуванням ремінісценції, що визначає більшу продуктивність і змістовність відстроченого відтворення інформації, доцільно пізніше запланувати проведення пред'явлення до впізнання неповнолітнього потерпілого, але не пізніше трьох-чотирьох днів із моменту злочинного посягання, оскільки потім може виникнути процес забування.

Ключові слова: неповнолітні потерпілі, психічний стан, злочини насильницького характеру, пред’явлення особи для впізнання.

Постановка наукової проблеми та іїі значення. Пред’явлення особи для впізнання за участю неповнолітнього $\epsilon$ слідчою дією, яка грунтується на психофізіологічних механізмах сприйняття, запам'ятовування, відтворення і полягає у ідентифікації зовнішності особи за уявним образом, що сформувався у дитини під час спостерігання певної особи [1, с. 82]. Діагностика і оцінка наслідків, в тому числі психологічних, пережитого насильства має значення не тільки для подальшої 
медико-соціальної реабілітації неповнолітньої особи, але і для вирішення питань, що виникають в рамках судово-слідчих дій, про здатність неповнолітніх потерпілих давати показання, про оцінку безпорадного стану, кримінально-процесуальну дієздатність [2, с. 13].

Аналіз досліджень цієї проблеми. Питання неповнолітніх учасників кримінального провадження завжди привертали увагу науковців. Зокрема, особливостями допиту неповнолітньої особи у кримінальному провадженні, займалися такі вчені, як В. П. Бахін, В.К. Весельский, А. Ф. Волобуєв, А. Є. Голубов, О. М. Крукевич, В. В. Романюк, В. С. Комарков, Л. П. Конишева, В. О. Коновалова, О. О. Кочура, С. В. Кузнецова, О. Ю. Лань, Є. Д. Лук'янчиков, В. В. Печерський, Г. І. Пичкальова, М. А. Погорецький, Н. Ш. Сафін, М. О. Селіванова, О. М. Сербулов, Д. Б. Сергєєва, О. Б. Соловйов, О. С. Старенький, В. Ю. Шепітько. Тему пред’явлення для впізнання висвітлювали Т. В. Авер'янова, Р. С. Бєлкін, В. А. Колесник, Ю. Г. Корухов, О. Ф. Зеленський, В. Ю. Шепітько, М. Г. Щербаковський та інші.

Мета дослідження. Незважаючи на тривалу історію досліджень, присвячених психологічній травмі, і активний інтерес з боку фахівців до проблеми жорстокого поводження щодо дітей та підлітків, до цих пір залишаються недостатньо розробленими критерії діагностики та оцінки реакцій на травму у дітей і підлітків. До теперішнього часу не була вироблена і описана феноменологічна модель психологічних наслідків насильства щодо неповнолітніх та впливу на тактику здійснення слідчих дій, зокрема проведення впізнання особи. Заповнення вказаних прогалин є метою цієї статті.

Виклад основного матеріалу й обгрунтування отриманих результатів дослідження. Залежно від приналежності до певної вікової групи неповнолітні за характером і ступенем вираження психічних процесів суттєво різняться між собою. Безсумнівно, здатність запам'ятовувати й потім відтворювати побачене є різною в п'ятирічної дитини та п'ятнадцятирічного підлітка. Так, на думку Н. В. Тарабріної, дуже важливо розглядати наслідки насильства, пережитого дитиною, враховуючи іiі вікові особливості. У різні періоди життя реакція на подібну психологічну травму може проявлятися по-різному. Найбільш загальними симптомами, залежно від віку дитини, $є$ :

- для дітей до 3 років - страхи, сплутаність почуттів, у поведінці відзначаються порушення сну, втрата апетиту, агресія, страх перед чужими людьми, сексуальні ігри;

- для дошкільнят - тривога, боязкість, сплутаність почуттів, почуття провини, сорому, огиди, відчуття безпорадності, зіпсованості; в поведінці відзначаються регресія, відстороненість, агресія, сексуальні ігри, мастурбація;

- для дітей молодшого шкільного віку - амбівалентні почуття по відношенню до дорослих, складності у визначенні сімейних ролей, страх, почуття сорому, огиди, зіпсованості, недовіри до світу; в поведінці відзначаються відстороненість від людей, порушення сну, апетиту, агресивна поведінка, відчуття «брудного тіла», мовчазність або несподівана балакучість, сексуальні дії 3 іншими дітьми;

- для дітей 9-13 років - те ж, що і для дітей молодшого шкільного віку, а також депресія, відчуття втрати відчуттів; у поведінці відмічаються ізоляція, маніпулювання іншими дітьми з метою отримання сексуального задоволення, суперечлива поведінка [3, с. 71-72]. Водночас, для дітей старшого шкільного віку характерні втечі з дому або інституційних установ, низька самооцінка, спроби самогубства, вживання наркотиків або алкоголю, проституція або безладні статеві зв'язки, психосоматичні розлади.

Н. В. Павлюк вказує на те, що результати анкетування слідчих МВС України показують, що найбільш суттєвими особливостями психіки неповнолітніх $є$ такі: конформність (22 \%); підвищена навіюваність (41\%); схильність до фантазування (59\%); почуття дорослості (58 \%); імпульсивність $(52 \%)$; негативізм (31\%); товариськість (24\%); прагнення до референта (5\%); фрагментарність сприйняття (19\%) [4, с. 9]. Таким чином, результативність такої слідчої дії, як пред’явлення до впізнання, проведеної за участі неповнолітнього потерпілого, безпосередньо залежить від знання слідчим як основних психологічних характеристик тієї вікової групи, до якої належить дитина, так і їі особистісних якостей. I якщо вивчення останніх відбувається здебільшого на стадії підготовки до слідчої (розшукової) дії, то одержання базових знань щодо вікової періодизації неповнолітніх елемент професійної підготовки слідчих. 3 огляду на це, перспективним напрямом розвитку слідчої тактики $є$ розроблення системи прийомів і рекомендацій щодо проведення пред'явлення до впізнання за участі представників різних вікових груп неповнолітніх потерпілих від насильства.

На формування психічних станів неповнолітніх потерпілих в момент безпосереднього вчинення насильницьких злочинів доволі часто впливають страх, біль і моральні страждання. Аналіз наукової літератури із судової психології дозволяе віднести до психічних страждань низку екстремальних емоційних станів людини, таких як: стан емоційної напруги та емоційного збудження, 
які здійснюють суттєвий вплив на свідомість та поведінку людини; стан початкової фази кумулятивного афекту; тривалий і сильний стресовий стан; стан фрустрації тощо [5, с. 152-154]. Однак, найбільш характерною реакцією неповнолітніх потерпілих від насильницьких злочинів на ситуацію нападу є почуття страху як емоційне відображення небезпечності, обумовленої невідомістю ситуації, невірою у власні сили, відсутністю інформації про сприятливий вихід із ситуації, що склалася. Почуття страху може проявлятися по-різному: від занурення у себе і пасивності до насильницької поведінки [6, с. 72-78].

Відомий психолог 3. Фрейд, визначає страх як психічний стан людини, який пов'язаний 3 тяжкими переживаннями і викликає дії, спрямовані на самозбереження, зазначаючи, що він властивий всім живим організмам. Автор виділяє декілька типів страху: 1) страх інфантильний дитячий страх, що спочатку є лише вираженням потреби постійно бути поряд з рідною людиною, але спостерігається і у дорослих як страх невротичний; 2) страх невротичний - різноманітні форми «безцільного страху» невротиків, що виникають як реакція на невизначену загрозу; 3) страх реальний - раціональний прояв інстинкту самозбереження як нормальна реакція на сприйняття зовнішньої небезпеки; 4) страх вільний - загальна невизначена боязливість, готова на деякий час «прив'язатися» до будь-якої нової можливості, що проявляється в «страху очікування»; страх безпредметний, не пов' язаний з певним об'єктом [7, с. 532].

Окрім цього, в психологічній літературі виділяють наявність різних форм почуття страху: астенічної, стенічної та афективної форм, а також стенічного бойового збудження. Астенічна форма страху, що виникає у жертви злочину, відображається i у внутрішніх психологічних процесах: паралізує волю потерпілої до опору, сприяє неадекватному відображенню ситуації, перебільшенню небезпечності [8, с. 432]. Наявність такої форми страху у неповнолітнього може призвести до перекручення потерпілим обставин злочину, до їх запам'ятовування у перекрученому вигляді тощо. Іншою формою страху, яка може виникнути у неповнолітнього потерпілого від насильницького злочину, є стенічна. Суть іiі полягає у активно-оборонному рефлексі, що дозволяє потерпілому чинити опір діям насильника. Водночас, у зв'язку зі спрямованістю розумової діяльності неповнолітнього потерпілого від насилля на оцінку обстановки і вибір засобів боротьби, його увага сконцентрована лише на окремих деталях події, інші деталі можуть запам'ятовуватись у перекрученому вигляді.

При вчиненні насильницького злочину з особливо брутальним впливом на неповнолітню особу іiі страх може перетворитися на почуття жаху. У разі, коли страх досягає сили афекту у формі панічного страху, жаху, він здатний нав'язати стереотипи поведінки у формі втечі, заціпеніння, захисної агресії [9, с. 398]. Жах, як афективна форма страху, пов'язаний з різкими змінами психічної діяльності неповінолітнього потерпілого від насильницького злочину, порушеннями логічності його мислення, розладами орієнтування в оточуючий обстановці та, як наслідок, може призвести до певних перекручувань у показаннях потерпілого при пред'явленні до впізнання. Почуття жаху i безпорадності, з якими стикаються неповнолітні потерпілі в ході переживання травматичних подій, на жаль, часто не лишаються в минулому і продовжують переслідувати їх в теперішньому житті. Вони можуть виникати чи не кожного разу, коли хтось або щось нагадує про травму. Водночас, в окремих ситуаціях нападу у неповнолітнього потерпілого від насильства виникає стенічне бойове збудження, під час якого розумова та психічна діяльність його активізується. Ця форма страху позитивно впливає на продуктивність сприйняття i запам'ятовування, точність, повноту i об'єктивність показань потерпілого. Таким чином, почуття страху у неповнолітнього потерпілого під час вчинення насильницького злочину може переходити з однієї форми в іншу. Про це певною мірою свідчить якість його показань про обставини вчинення злочину: уривчаста і перекручена картина на початку нападу та чіткі спогади про подальшу боротьбу і навпаки. Вищевикладене свідчить, що страх, який відчуває неповнолітній потерпілий в момент нападу, значно впливає на формування його подальших показань та має бути врахований слідчими працівниками під час розслідування насильницького злочину. Для жертв насильницьких злочинів характерним $є$ і фізичний вплив: побої, поранення, збочення і т.д. Тож, почуття страху доповнюється відчуттям болю. Разом з тим, дія почуття страху на почуття болю може бути прямо протилежною за своїми наслідками. Так, в одних випадках через почуття страху біль посилюється; в інших, навпаки, пригнічується (реакція на біль може з'являтись через деякий час через анестезуючу дію страху) [10, с. 229].

Аналіз матеріалів судової і слідчої практики доводить, що не завжди відповідають дійсності показання неповнолітніх потерпілих від насильницьких злочинів про фізичне насильство. Зокрема, про особу нападника, тривалість злочинного нападу, кількість та ступінь нанесених ударів, силу їх заподіяння тощо. Нейтралізувати такі негативи та об'єктивно оцінити показання потерпілих 
неповнолітніх від насильницьких злочинів допоможуть методи порівняльних досліджень, зокрема, співставлення показань потерпілих як 3 даними судово-медичної експертизи про наявність, локалізацію та ступінь тяжкості тілесних ушкоджень, так і з іншими відомостями у справі. Так, у справі Ворошиловського районного суду м. Донецька покази потерпілого ОСОБА_2 суд вважає правдивими та спроможними, оскільки надані ним свідчення є логічними, послідовними та такими, що підтверджуються іншими доказами, дослідженими судом [11].

Особливістю свідчень неповнолітніх потерпілих від насильницьких злочинів $є$ також те, що вони відрізняються підвищеною емоційністю, причому в емоційній пам'яті довго зберігається те, що вони пережили при взаємодії зі злочинцем, - біль, фізичні страждання, страх, жах, відчай, колізії боротьби, тобто комплекс стресового перенапруження. На думку С. Шмерецького, як наслідок, можливе виникнення так званого «слідового» афекту, психогенних реактивних станів, невротичних i психотичних розладів [12, с. 147]. Вбачаємо, доцільним призначення щодо неповнолітнього потерпілого від насильницького злочину певних видів експертиз (у тому числі комплексних чи(i) комісійних) та залучення фахівців-психологів до слідчих дій за участю потерпілих. Результати вивчення слідчої практики доводять, що в слідчого часто бракує часу для одержання висновків експерта про психічний стан неповнолітнього, а показання дитини $є$ дуже важливими для вибору напряму розслідування насильницького злочину. Зважаючи на цю обставину, В. Пясковський пропонує використовувати результати психолого-психіатричної експертизи неповнолітнього щодо встановлення рівня його психічного розвитку, здатності правильно сприймати, розуміти й оцінювати події, що відбулися за його участі, а також інші обставини, не до проведення слідчих (розшукових) дій, а після, що дасть змогу не тільки скоротити строки розслідування завдяки очікуванню результатів експертизи, а й слугуватиме відповідним доказом об'єктивності показань [13, с. 176].

За даними психологів, у більшості неповнолітніх потерпілих, які зазнають насильства, спостерігається явище деперсоналізації. У дітей знижується пізнавальна діяльність, коли вони відчувають себе не учасником, а лише спостерігачем того, що відбувається з його тілом, тобто втрачає особистісну визначеність [14, с. 57-59]. Деперсоналізація впливає на процес впізнання неповнолітніх потерпілих від насильницьких злочинів. Тому, з метою встановлення достовірності перевірки отриманих показань доцільно ставити відповідні запитання експерту при судовомедичному, судово-психологічному чи судово-сексологічному дослідженні неповнолітнього потерпілого. Експертне підтвердження дії на деперсоналізацію сприятиме визначенню суб' єктивних і об'єктивних умов формування показань неповнолітніх потерпілих від насильства.

Психічний стан неповнолітніх потерпілих від насильницьких злочинів після вчинення злочину до моменту звернення у правоохоронні органи, як правило, обумовлений приниженням, образою, страхом, біллю, моральними стражданнями тощо. Особливо за умови, якщо неповнолітня жертва була знайома з винним, з боку якого чи його родичів, знайомих мають місце різного роду погрози. Характерними в даному випадку для неповнолітніх $\epsilon$ апатія, байдужість, бажання покінчити 3 собою. Залежно від виду вчиненого щодо неповнолітньої особи насильницького злочину, зазначений стан може ускладнюватись відчуттям сорому, каліцтвом, інвалідністю потерпілого тощо. Як слушно зауважує Н. М. Максимишин, на формування показань впливають психоемоційний стан допитуваного в момент судового відтворення показань (переживання, спокій, відчуття смутку, сорому і т.д.) та вплив психологічного захисту індивіда [15, с. 46]. Варто зауважити, що психічний стан неповнолітніх потерпілих від насильницьких злочинів не $\epsilon$ однозначним. Так, у післякримінальній ситуації, за даними психологів, потерпілий може відчувати і повний спокій чи радість, наприклад, від того, що залишився живим [16, с. 86-87]. Зазначені відчуття асоціюються 3 впевненістю у собі, відчуттям здатності подолати життєві перешкоди. Такий психічний стан неповнолітніх потерпілих від насильницьких злочинів, на мій погляд, має позитивний вплив на формування їх показань.

Водночас, психічний стан неповнолітнього потерпілого обумовлюється соціальними наслідками злочину, зокрема, погіршення психічного здоров'я неповнолітнього потерпілого, лікування, сліди нанесених побоїв і ушкоджень, зміни у взаємовідносинах з членами сім'ї, родичами, знайомими, сусідами, колегами, як правило, пов'язані з його відлюдністю, неврівноваженістю, роздратованістю, депресією, обмеженням звичного кола соціальних контактів, неможливістю продовження активного громадського та особистого життя [17, с. 126]. У зв'язку з цим, слідчому доцільно під час пред'явлення до впізнання неповнолітнім потерпілим з'ясовувати та відображати в протоколі цієї слідчої дії, що саме вона відчуває, як характеризує свій стан.

Не можна не погодитися з думкою багатьох як вітчизняних, так і зарубіжних віктимологів про те, що кримінальне судочинство, численні бесіди 3 дитиною про вчинений злочин можуть завдати 
йому більшої шкоди, ніж сам злочин, оскільки судовий розгляд знову і знову викликає в пам'яті процес злочину i, крім цього, ставить дитину в психологічно скрутне становище щодо оточуючих [18, c. 85$]$.

На думку Є.Є. Шмерецького, особливістю свідчень потерпілих від насильницьких злочинів є те, що вони відрізняються підвищеною емоційністю, при чому в емоційній пам'яті довго зберігається те, що вони пережили під час взаємодії із злочинцем, біль, - фізичні страждання, страх, жах, відчай, колізії боротьби, тобто комплекс стресового перенапруження. Як наслідок, можливе виникнення «слідового» афекту, психогенних реактивних станів, невротичних і психотичних розладів [19, с. 143].

Варто пам'ятати, що неповнолітня особа, до якої було застосоване насильство, нанесена травма здоров'ю та психологічному стану, природно, знаходиться під впливом негативних, пригнічуючих емоцій та прагне встановлення справедливості і покарання винних. В результаті надані неповнолітнім потерпілим свідчення та зібрані ним докази можуть носити заангажований, суб' єктивний характер, де чітко прослідковуватиметься його особиста позиція та прагнення негайного покарання винуватців. Як слушно зауважує С. Семенко, у такому випадку необхідно розглядати надані потерпілим докази у комплексі з показами свідків та оцінювати їх у сукупності 3 іншими доказами [20, с. 160]. В ході пред'явлення до впізнання неповнолітнього потерпілого від насильницького злочину для отримання необхідних у справі доказів слід брати до уваги те, наскільки суб'єктивними можуть бути покази потерпілого, який виступає насамперед зацікавленою стороною, покази якої, як стверджує А. Р. Ратинов, варто піддавати критичному аналізу [21, с. 50-51].

Збудження, напружено-емоційний стан неповнолітнього потерпілого суттєво гальмують процес відтворення ним показань. Тому 3 урахуванням ремінісценції, що визначає більшу продуктивність і змістовність відстроченого відтворення інформації, доцільно пізніше запланувати проведення пред'явлення до впізнання неповнолітнього потерпілого, але не пізніше трьох-чотирьох днів із моменту злочинного посягання, оскільки потім може виникнути процес забування.

Висновки. У результаті проведеного дослідження зроблено висновки про те, що психічний стан неповнолітнього потерпілого від насильницького злочину, як відносно стійкий прояв всіх компонентів психічної діяльності, обумовлений характером і психічними властивостями особистості потерпілого, його попереднім психічним станом, обставинами злочинного впливу, видом завданої шкоди, ситуацією розслідування і проведення слідчої дії, іншими факторами. Психічний стан неповнолітніх потерпілих від насильницьких злочинів знаходить свій прояв у своєрідності їх психічних процесів, показань, поведінки й ставлення до справи на досудовому та судовому слідстві. Він $є$ основою формування показань неповнолітніх потерпілих від насильства та обумовлює певні перекручення в початковій інформації про злочин, що міститься в їхніх усних чи письмових повідомленнях. Тривалість, ступінь та характер впливу психічного стану на неповнолітнього потерпілого, ступінь його усвідомленості потерпілим, адекватність ситуації, домінування в ньому того чи іншого компонента впливають на обрання слідчим тактики слідчих дій за участю потерпілого, на оцінку слідчим іiі показань, отриманих при пред'явленні до впізнання позиції та поведінки у передкримінальній, кримінальній та післякримінальній ситуаціях. Знання та врахування слідчим психічних станів $є$ необхідною умовою успішної організації і проведення не лише слідчих дій за участю неповнолітніх потерпілих, але, й розслідування насильницьких злочинів, вчинених щодо них, у цілому.

\section{Джерела та література}

1. Карпінська Н., Ліщинська-Мартинюк О. Деякі проблемні питання пред’явлення особи для впізнання неповнолітньому потерпілому від злочинів насильницького характеру / Н. Карпінська, О. Ліщинська-Мартинюк // Історико-правовий часопис. - 2019. - №1 (13). - С. 80-84

2. Гурьева В. А., Морозова Н. Б. Острые аффективные реакции у несовершеннолетних с психогенным развитием личности (клиника, диагностика, судебно-психиатрическая оценка): метод. рекомендации / В. А. Гурьева, Н. Б. Морозова. - М., 1990. - 16 с.

3. Тарабрина Н. В. Практикум по психологии посттравматического стресса / Н. В. Тарабрина. - СПб.: Питер, 2001. - 272 с.

4. Павлюк Н. В. Процес формування показань неповнолітніх (інтерпретація та використання під час допиту): автореф. дис. канд. юрид. наук / Н. В. Павлюк. - Х., 2011. - 21 с.

5. Нагаїв В. В. Основы судебно-психологической экспертизы. Учеб. пособие для вузов / В. В. Нагаїв. - М.: ЮНИТИ-ДАНА, Закон и право. - 2000. - 333 с. 
6. Гаврилова Т. В. Социальные аспекты распространения насилия в отношении несовершеннолетних /

Т. В. Гаврилова // Криминологический журнал ОГУЕП. - 2012. - № 3 (21). - С. 72-78.

7. Фрейд 3. Вступ до психоаналізу: лекції зі вступу до психоаналізу з новими висновками [Текст] /

3. Фрейд. - Київ: Основи, 1998. - 709 с.

8. Павлов И. П. Полное собрание сочинений. - T. IV / И. П. Павлов. - М. -Л., 1951. - 432 с.

9. Бандурка А. М. Юридическая психология / А. М. Бандурка. - Х., 2005. - 432 с.

10. Шафранская К. Д. К изучению человека в экстремальных условиях / К. Д. Шафранская // Человек и общество. - 1967. - Вып. 2. - С. 229.

11. Вирок Ворошиловського районного суду м. Донецька від 27 березня 2014 року у справі № 255/13942/13-к [Електронний ресурс]. - Режим доступу: http://reyestr.court.gov.ua/Review/37915942.

12. Шмерецький С. С. Юридико-психологічна характеристика згвалтування: дис. канд. юрид. наук / Є. Є. Шмерецький. - К., 2018. - 222 с.

13. Пясковський В. Особливості перевірки доказів, отриманих за участі неповнолітніх потерпілих від насильницьких злочинів / В. Пясковський // Юридичний часопис Національної академії внутрішніх справ. - 2015. - № 2 (10). - С. 172-181.

14. Зейгарник Б. В. Патопсихологія / Б. В. Зейгарник. - М., 1976. - 287 с.

15. Максимишин Н. М. Судовий допит: процесуальне і криміналістичне дослідження: дис. канд. юрид. наук / Н. М. Максимишин. - Львів, 2016. - 250 с.

16. Кравцова О. А. О психологических последствиях сексуального насилия / О. А. Кравцова // Вестник МГУ. Сер. «Психология». - 1999. - № 2. - С. 86-87.

17. Центров Е. Е. Криминалистическое учение о потерпевшем / Е. Е. Центров. - М., 1988. - 160 с.

18. Вишневецький К. Криминологическая характеристика несовершеннолетних жертв семейного насилия / К. Вишневецкий // Власть. - 2008. - № 4. - С. 84-86

19. Шмерецький Є. С. Психологічні особливості допиту потерпілої від згвалтування / Є. Є. Шмерецький // Науковий вісник публічного та приватного права. - 2016. - Вип. 6. - Т. 2. C. $139-144$.

20. Семенко С. Психологічні особливості процесу доказування у справах, порушених за скаргою потерпілого / С. Семенко // Європейські перспективи. - 2012. - № 2. - Ч.1. - С. 158-162.

21. Ратинов А. Р. Судебная психология для следователей / А. Р. Ратинов. - М., 2001. - 352 с.

Лещинская-Мартынюк О. Тактика предъявления личности для опознания сквозь призму учета психического состояния несовершеннолетних потерпевших от насильственных преступлений. В статье освещаются вопросы особенностей психического состояния несовершеннолетних потерпевших от насильственных преступлений. Раскрыты особенности психики несовершеннолетних в разные возрастные периоды и обычные реакции на психологическую травму. Особое внимание уделено учету психических состояний несовершеннолетних потерпевших от насильственных преступлений при организации предъявления лица для опознания. Обосновано положение о том, что психическое состояние несовершеннолетних потерпевших от насильственных преступлений находит свое проявление в своеобразии их психических процессов, является основой формирования показаний и обусловливает определенные искажения первичной информации о преступлении и должно быть исследовано и учтено следователем при выборе тактики предъявления несовершеннолетнему потерпевшему для опознания другого человека. Продолжительность, степень и характер влияния психического состояния на несовершеннолетнего потерпевшего, степень его осознанности пострадавшим, адекватность ситуации, доминирование в нем того или иного компонента влияют на избрание следователем тактики следственных действий с участием потерпевшего, на оценку следователем его показаний, полученных при предъявлении для опознания. Напряженно-эмоциональное состояние несовершеннолетнего потерпевшего существенно тормозят процесс воспроизводства ним показаний. Поэтому с учетом реминисценции, что определяет большую производительность и содержательность отсроченного воспроизведения информации, целесообразно позже запланировать проведение предъявления к опознания несовершеннолетнего потерпевшего, но не позднее трех-четырех дней с момента преступного посягательства, поскольку потом может возникнуть процесс забывания.

Ключевые слова: несовершеннолетние потерпевшие, психическое состояние, преступления насильственного характера, предъявление для опознания. 
Lishchynska-Martyniuk O. Tactics of Presenting a Person for Identification Taking into Account the Mental State of the Juvenile Victims of Violent Crimes. The article highlights the issue of the mental state peculiarities of minors who are victims of violent crimes, the features of the juvenile psyche in different age periods, and their most common reactions to psychological trauma. When presenting a person for identification, particular attention is paid to the mental health of the minors - victims of violent crimes. The author argues that the mental state of juvenile victims of violent crimes is manifested in the peculiarity of their mental processes, is the basis of the formation of testimonies, and causes some misrepresentation of the primary information about the crime. It should be taken into account by the investigator in choosing the tactics of presenting a person for identification to a minor victim. The duration, degree and nature of the influence of the mental state on the minor victim, the degree of his awareness of it, the adequacy of the situation, the dominance of one or another situational component influence the choice of the investigator's tactics in investigative actions involving assistance of the victim, and the assessment of his/her testimony obtained at presentation for identification. The tense and emotional state of the juvenile victim significantly inhibits the process of reproducing his testimony. Therefore, taking into account the reminiscence, which determines the greater productivity and content of delayed reproduction of information, it is advisable to plan the presentation for identification of the juvenile victim later, but not later than three or four days after the crime, because then there may be a process of forgetting.

Key words: juvenile victims, mental state, violent crimes, presenting a person for identification.

УДК 342.739

DOI https://doi.org/10.32782/2409-4544/2019-2/24

I. Озімок

\section{Конституційно-правове регулювання права власності на землю в Україні}

Земля як об'єкт права власності регулюється в першу чергу цивільним, екологічним i земельним законодавством. Разом 3 тим, конституційно-правове регулювання права власності на землю має визначальний характер для всіх галузей права. Конституція України досить змістовно регулює право власності на землю, визнаючи землю природним ресурсом і об'єктом права власності. Крім того, конституційними нормами регулюються окремі питання форм власності, принципи реалізації права власності, захист і гарантованість права власності на землю, містяться вказівки на суб'єктів права власності на землю, а також обов'язок не використовувати власність на шкоду людині і суспільству. Така правова регламентація конституційного права власності на землю в порівнянні 3 конституціями багатьох країн світу є більш детальної, що безпосередньо пов'язано з важливістю землі для вітчизняної економіки і національної безпеки. Подібне правове регулювання частково спостерігається в конституціях низки пострадянських країн, в яких землях відводиться особливе місце в конституційно-правовому регулюванні. Ст. 14 Конституції України розвиває принципові положення, закріплені в ст. 13 Основного Закону. Вона визначає структуру земельного законодавства та закріплює основні засади регулювання земельних відносин у сучасних умовах і на перспективу. У ній також визначається правовий режим одного з найважливіших природних ресурсів - землі, яка визнана основним національним багатством, що перебуває під особливою охороною держави. Питання щодо права власності на землю мають регламентуватись виключно законами як актами вищої юридичної сили, прийнятими Верховною Радою України відповідно до встановленої процедури.

Ключові слова: Конституція України, право власності, право власності на землю

Постановка наукової проблеми та її значення. Розглядаючи землю як об'єкт правового регулювання, теоретики і практики виходять в першу чергу з розуміння землі як об'єкта права власності. В умовах триваючої земельної реформи інтерес до пошуку оптимальних шляхів врегулювання права власності на землю не вщухає. Земля, як об'єкт права власності, регулюється в першу чергу цивільним, екологічним та земельним законодавством. Разом з тим, конституційно-

(ㄷ) Озімок I., 2019 